\title{
Callus Induction and Phytochemical Constituents of Finger Eggplant (Solanum sp.)
}

\author{
Norhayati DAUD ${ }^{1, *}$, Norizzah Jaafar SIDIK ${ }^{2}$, \\ Som Cit SINANG ${ }^{1}$ and Nurul Fazira OMAR ${ }^{2}$ \\ ${ }^{I}$ Department of Biology, Faculty of Science and Mathematics, Universiti Pendidikan Sultan Idris, \\ Perak Darul Ridzuan, Malaysia \\ ${ }^{2}$ Department of Biology, Faculty of Applied Science, Universiti Teknologi MARA, Selangor, Malaysia
}

('Corresponding author's e-mail: norhayati.daud@fsmt.upsi.edu.my)

Received: 12 April 2019, Revised: 19 August 2019, Accepted: 13 September 2019

\begin{abstract}
This study examined the efficiency of callus induction on optimum concentrations of NAA $(\alpha-$ naphthaleneacetic acid) and BAP (6-benzyladenine) from culturing stem and leaf explants of finger eggplant (Solanum sp.) and investigated the phytochemical constituents of callus tissue. Seeds were sterilized by using 3 and $5 \%$ Clorox solution, which gave the highest number of survival seeds $(100 \%)$ and were grown in vitro plantlets. The highest frequency of callus induction $(100.00 \pm 0.00 \%)$ was obtained from stems and leaf explants that were excised from in vitro plantlets. The stem explants cultured on MS medium consisted of $1.0 \mathrm{mg} / \mathrm{L} \mathrm{NAA}+1.0 \mathrm{mg} / \mathrm{L}$ BAP, giving the maximum mean callus fresh weight $(0.14 \pm 0.05 \mathrm{~g})$. Meanwhile, the leaf explants cultured on MS medium consisted of $0.5 \mathrm{mg} / \mathrm{L}$ $\mathrm{NAA}+2.0 \mathrm{mg} / \mathrm{L} \mathrm{BAP}$, generating the maximum mean callus fresh weight $(0.48 \pm 0.10 \mathrm{~g})$. The highest frequency of callus induction $(88.00 \pm 1.60 \%)$ was obtained in solidified MS medium supplemented with $0.5 \mathrm{mg} / \mathrm{L} \mathrm{NAA}+2.0 \mathrm{mg} / \mathrm{L}$ BAP, producing the maximum mean fresh weight of callus $(1.54 \pm 0.27 \mathrm{~g})$ and dry weight $(0.90 \pm 0.01 \mathrm{~g})$. The results of the Phytochemical screenings of callus and dried leaf extracts indicated the presence of alkaloids, flavonoids, terpenoids, and saponins.
\end{abstract}

Keywords: Solanum sp., Finger eggplant, NAA, BAP, Callus, Phytochemical constituent

\section{Introduction}

Finger eggplant (Solanum sp.) belongs to the plant family Solanaceae commonly known as 'terung telunjuk' (in Malay), one of the local eggplant varieties in Malaysia with small size, long fruit shape and yellowish skin color of ripe fruits, low yield and commonly used as salad or ulam (in Malay) [1]. This variety is considered as a wild progenitor of brinjal eggplant (Solanum melongena L.) as it grows wild in bushes-rural areas, i.e. at the rural ecological gradient. Finger eggplant has been reported used as a traditional medicine against several diseases. The leaves down to the roots of this plant can allegedly be used to treat several diseases, such as asthma, toothache, and swollen gums, and relieve cough [2]. Compared to the eggplant $S$. melongena L., a highly productive crop and consumed as a cooked vegetable in various ways, the finger eggplant (Solanum sp.) is not suitable for vegetables. As this species grows wild and produces low yield, it has no potential to meet the demand as commercial crops.

Solanaceae family comprises some plants widely known for the presence of a variety of secondary metabolites such as alkaloids, flavonoids, saponins, steroids, tannins, terpenoids, and phenolic compounds [3]. The presence of the alkaloid (solasodine) has been identified to have the character of a Solanum genus, which has economic advantages and is useful in medicine [4]. Currently, the demand for herbal medicine or phytomedicine using plant parts is increasing. Plant secondary metabolites can be 
http://wjst.wu.ac.th

attained by extracting directly from plant parts and have medicinal values. Therefore, there is a need for an alternative method to overcome or to compensate for the increase in demand of these secondary metabolites, instead of the conventional method from a crude extract of the plant.

Plant tissue cultures method through in vitro callus offers an alternative method as a potential tool for the production of secondary metabolites [5]. Recently, callus tissues have been proven better for the synthesis of secondary metabolites [6]. Successful callus induction depends on many factors such as genotype, explants, culture media, hormones, and culture condition. It has been shown previously for many plant species, including representatives of the family of Solanaceae such as roots, leaves, rooted hypocotyls, nodal segments, and petioles explants of $S$. nigrum L [7] and, genotype and plant growth of $S$. melongena L. [8]. The most influential hormone in determining the growth and production of secondary metabolites is a group of auxins and cytokinin. The optimum culture conditions and high-frequency callus induction of Solanum nigrum L. were obtained on MS medium supplemented with NAA and BAP utilizing leaves explants. The phytochemical screenings of the crude plant extract and its callus revealed the presence of alkaloids, saponins, tannins, flavonoids, and phenolic [9].

The tissue culture system provides an alternative to callus initiation with much potential for the production of secondary metabolites. Callus production requires only a small part of the leaf or stem of plants as an explant rather than using a leaf and stem parts directly with a large amount and can eventually contribute to the extinction of the species. Therefore, reliance on medicinal plants needs to be conserved and efforts to avoid extinction need to be done. Moreover, the development of callus induction and phytochemical constituents on finger eggplant (Solanum sp.) have not been reported earlier. Based on the previous study on several species of the Solanum genus, an attempt is made to the protocol for callus initiation and screening the phytochemical constituents of callus in finger eggplant (Solanum sp.).

Correspondingly, the study aimed to define the callus induction from culturing the stem and leaf explants on optimum concentrations of hormones (NAA and BAP) of the finger eggplant (Solanum sp.) besides investigating the phytochemical constituents of callus tissue. The success of callus induction protocol of finger eggplant (Solanum sp.) can be used to create new varieties with desirable traits in the future and to be important in terms of medicinal and nutritive properties.

\section{Materials and methods}

\section{Plant material and sterilization}

Mature fruits with seeds of finger eggplant (Solanum sp.) were collected from plants growing in bushes-rural areas. Herbarium vouchers were prepared and deposited in UPSI herbarium. All experiments were conducted at Research Laboratory, Department of Biology, Faculty of Science and Mathematics, Universiti Pendidikan Sultan Idris (UPSI), Perak, Malaysia. For the sterilization procedure, the fruits washed with running tap water and Tween-20 for $10 \mathrm{~min}$, then The surface sterilized with $70 \%(\mathrm{v} / \mathrm{v})$ Clorox solution (commercial bleach) for $3 \mathrm{~min}$, then rinsed using $70 \%(\mathrm{v} / \mathrm{v})$ ethanol for 1 min. Finally, the fruits were rinsed with sterile distilled water 5 times. After the fruits completed the pre-sterilization procedure, the seeds washed with distilled water in the centrifuge at $13 \mathrm{rpm}$ for $1 \mathrm{~min}$, followed by $2 \mathrm{ml}$ of 70, 50, and $30 \%(\mathrm{v} / \mathrm{v})$ Clorox solution and ethanol solution spun at $13 \mathrm{rpm}$ for $5 \mathrm{~min}$ respectively, then rinsed with sterile distilled water by spinning at $13 \mathrm{rpm}$ for $1 \mathrm{~min}$. Finally, the seeds were rinsed with sterile distilled water 5 times in a laminar flow chamber. Twenty-five sterile seeds were then cultured on basal MS medium.

\section{Culture medium preparation}

The culture medium used was Murashige and Skoog [10] (MS) basal medium consisted of $4.4 \mathrm{~g} / \mathrm{L}$ MS medium in powdered form supplemented with $30 \mathrm{~g} / \mathrm{L}$ sucrose and solidified using $8 \mathrm{~g} / \mathrm{L}$ Oxoid technical agar. The MS media supplemented with varying concentrations of NAA and BAP were used in the study of callus formation. The $\mathrm{pH}$ of MS media was adjusted 5.6 to 5.8 by adding $1.0 \mathrm{~N} \mathrm{HCl}$ or $1.0 \mathrm{~N}$ $\mathrm{KOH}$ after the addition of hormones were autoclaved at $121^{\circ} \mathrm{C}, 15 \mathrm{psi}\left(1.2 \mathrm{~kg} / \mathrm{cm}^{3}\right)$ for $15 \mathrm{~min}$. 
http://wjst.wu.ac.th

\section{Culture condition}

Three experiments were carried out for callus induction of finger eggplant (Solanum sp.):

Experiment 1: Sterilized seeds were cultured onto sterile culture MS basal medium (without hormones) in the sterilized jar. After 2 weeks of the seeds culture, contamination (\%) and survival (\%) were estimated. Sterile (in vitro) plantlets were observed within 4 weeks under culture room condition.

Experiment 2: Stem $(2.0 \mathrm{~cm})$ and leaf $\left(0.5 \times 0.5 \times 10^{-2} \mathrm{~cm}^{3}\right)$ segments were dissected from 4 weeks old in vitro plantlets were cultured on MS medium supplemented with NAA (0.0 to $1.0 \mathrm{mg} / \mathrm{L})$ and BAP $(0.0$ to $3.0 \mathrm{mg} / \mathrm{L})$ hormones varying in concentrations. The distal section of leave was cultured horizontally where the adaxial surface touches the medium. The callus was subculture on fresh MS medium every 4 weeks of culture.

All the cultures were incubated in the culture room condition under a photoperiod of $16 \mathrm{~h}$ light and $8 \mathrm{~h}$ darkness at $25 \pm 1{ }^{\circ} \mathrm{C}$ with a light intensity of 1,000 lux provided by cool-white, fluorescent tubes. The basic observations were done weekly within 4 weeks.

Detail regarding callus growth was the percentage (\%) of callus formation, morphological characteristics of the callus, and weight $(\mathrm{g})$ of callus were observed and recorded 8 weeks later. The formula to calculate the percentage of callus formation was shown below [11].

Percentage of callus formation $(\%)=\underline{\text { Number of explants induced callus }} \times 100 \%$

Number of explants cultured

Morphological characteristics that referred to the callus texture and color were observed for each treatment. The observed parameters of weight callus that referred to their fresh weight and dry weight were recorded 8 weeks later. The callus was weighted, and the fresh weight was measured and then was dried at $50{ }^{\circ} \mathrm{C}$ for $48 \mathrm{~h}$ in the oven until the weight became constant.

\section{Extraction of plant materials}

The leave samples were dried in the oven at $50{ }^{\circ} \mathrm{C}$ for $48 \mathrm{~h}$, then grounded into a fine powder while callus was dried in the oven at $50{ }^{\circ} \mathrm{C}$ for $24 \mathrm{~h}$. All phytochemical tests were conducted on dried powdered leave and callus samples before taken and deposited into 3 different organic solvents such as hexane, dichloromethane, and methanol. These 3 solvents were chosen based on the polarity of the solvent (polar and non-polar solvents). A $100 \mathrm{~g}$ of dried powdered leaves were extracted in $500 \mathrm{~mL}$ of 3 different solvents for $48 \mathrm{~h}$. Dried callus $(50 \mathrm{~g})$ was soaked in $250 \mathrm{ml}$ of different solvents for $24 \mathrm{~h}$. The extracts were filtered and concentrated to dryness in a rotary evaporator. The yield of extracts was measured and recorded.

\section{Preliminary phytochemical screening}

All extracts of callus and leaves in different solvents were subjected to phytochemical screening quantitatively following the standard procedures method as described [12-14].

Test for Alkaloids: Crude extracts $(0.5 \mathrm{~g})$ were dissolved in dilute $(1 \%)$ hydrochloric acid $(\mathrm{HCl})$ and filtered. A few drops of Dragendorff's reagent are added to treat $2-3 \mathrm{~mL}$ of the filtrate. It was observed whether the alkaloids were present in the formation of an orange precipitate [14].

Test for Flavonoids: $5 \mathrm{~mL}$ of dilute ammonia solution were added to a portion of the crude extract followed by addition of the concentrated $\mathrm{H}_{2} \mathrm{SO}_{4}$. A yellow coloration observed in each extract indicated the presence of flavonoids $[12,13]$.

Test for Terpenoids: The Salkowski's test was undertaken to detect if terpenoids were present. Crude extracts $(0.2 \mathrm{~g})$ were mixed in $2 \mathrm{ml}$ of chloroform and $3 \mathrm{ml}$ of concentrated $\mathrm{H}_{2} \mathrm{SO}_{4}$. A reddishbrown color of the interface indicated the presence of terpenoids [12].

Test for Saponins: Distilled water $(5 \mathrm{~mL})$ was added to $0.5 \mathrm{~g}$ of extract in a test tube. The solution was shaken vigorously and observed for a stable persistent froth. Aqueous extract $(5 \mathrm{~mL})$ of was added to 1 - 3 drops of $3 \%$ ferric chloride solution. A white precipitate was developed which indicates a positive result [14]. 
http://wjst.wu.ac.th

Test for Tannins: The crude extract $(0.5 \mathrm{~g})$ was boiled in $10 \mathrm{ml}$ of distilled water in a test tube and then filtered. The filtrate was treated with 5 drops of $1.0 \%$ lead acetate solution. The development of greenish-blue precipitate is an indicator of the presence of tannins [14].

\section{Statistical analysis}

All experiments of the culture tissue system were carried out in 20 replicates of explants and presented as mean \pm standard error of (SE) using SPSS version 20.0. Post hoc multiple comparisons Tukey's Honestly Significant Difference (HSD) test was used to analyze the homogeneous subsets of the collected data. The statistical significance of the differences between means was predicted at $95 \%$ of confidence interval $(p<0.05)$.

\section{Results and discussion}

\section{Sterilization and incubation condition}

Two sterilizing agents (Clorox solution and ethanol) are used to sterilize the seeds with different concentrations and durations of spinning exposure. The seeds were collected from mature fruits (Figure 1). The embryos were easily separated from surrounding tissues after spinning in the centrifuge. The result shows that in vitro plantlet was developed after 4 weeks of culture. Based on the results (Table 1), the concentration of 3 and $5 \%$ Clorox solution with $13 \mathrm{rpm}$ for 3 min spinning resulted in $100 \%$ seeds survive and grow to be $100 \%$ in vitro plantlet (Figure 2) whereas, at low concentration (1\%), only $80 \%$ percentage seeds survive and developed in vitro plantlet. The lower concentration of ethanol (30 and 50 $\%$ ) showed a high percentage of contamination (32 and $20 \%$ ), and a lower percentage of seeds (68 and $80 \%$ ) developed to in vitro plantlets. By increasing the concentration (70\%) ethanol, only $80 \%$ of seeds survived and developed an in vitro plantlet. However, no fungus and bacteria contamination were observed because $20 \%$ (5) seeds did not survive or were dead after sterilization.

Sterilization is an essential pre-requisite to obtain the aseptic seedling for any in vitro system. The first experiment was aimed at finding the most suitable sterilizing agent. Explants contamination is depending on plants itself that related to environmental factors such as species, age, explants source, and prevailing weather condition [15]. Our results revealed that high concentration of Clorox solution (3 and 5 $\%$ ) was effective for controlling contamination. However, the ethanol at concentrations 30, 50, and $70 \%$ showed unsatisfactory results. By using $70 \%$ ethanol, a duration of 5 min treatment was found to be effective in suppressing the microbial contamination but was toxic to the seeds. This might be due to the effectiveness of the Clorox solution and the suitability of duration of spin exposure used during the process of surface. Non-survival seeds arisen due to damages that occurred during the sterilization procedure. Even if the surface is sterilized, the contaminants possibly come from the inner tissues during the dissection of fruits. Debergh and Zimmerman [16] stated that plant materials from the field were often more contaminated as compared to a greenhouse. The contaminations of seeds also expected due to part of the seeds coat is not excised during the spun exposure. Besides that, the presence of microorganisms at the surface layer of seeds was not completely killed after sterilization. The types of contaminants of plant tissue culture were bacteria and fungi, including spores [17]. Similar to the present study, the fungus contamination occurred more frequently. Singh [18] reported that the culture medium used in tissue culture techniques where the nutrients required for the plants and also the most suitable for the growth of the microbes because of having rich nutrients. Microbial growth in the media is due to improper sterilization. 
http://wjst.wu.ac.th

Table 1 Effect of seeds sterilization procedure by using Clorox solution and ethanol with different concentrations on growth, contamination, and survival of seed culture.

\begin{tabular}{llccc}
\hline \multicolumn{1}{c}{ Treatments } & $\begin{array}{c}\text { Duration spin } \\
\text { exposure }\end{array}$ & $\begin{array}{c}\text { Contamination (\%) } \\
\text { No. of seed }\end{array}$ & $\begin{array}{c}\text { No. of seed } \\
\text { survival }\end{array}$ & $\begin{array}{c}\text { In vitro Plantlet } \\
\mathbf{( \% )}\end{array}$ \\
\hline $\mathbf{5 \% \text { Clorox solution }}$ & $\mathbf{1 3}$ rpm for 3 mins & $\mathbf{0}$ & $\mathbf{2 5}$ & $\mathbf{1 0 0}$ \\
$\mathbf{3}$ \% Clorox solution & $\mathbf{1 3}$ rpm for 3 mins & $\mathbf{0}$ & $\mathbf{2 5}$ & $\mathbf{1 0 0}$ \\
$1 \%$ Clorox solution & 13 rpm for 3 mins & $20(5)$ & 20 & 80 \\
$70 \%$ ethanol & 13 rpm for 5 mins & $20(5)$ & 20 & 80 \\
$50 \%$ ethanol & 13 rpm for 5 mins & $20(5)$ & 20 & 80 \\
$30 \%$ ethanol & 13 rpm for 5 mins & $32(8)$ & 17 & 68 \\
\hline
\end{tabular}

*Total number of seed $=25$ for each treatment.

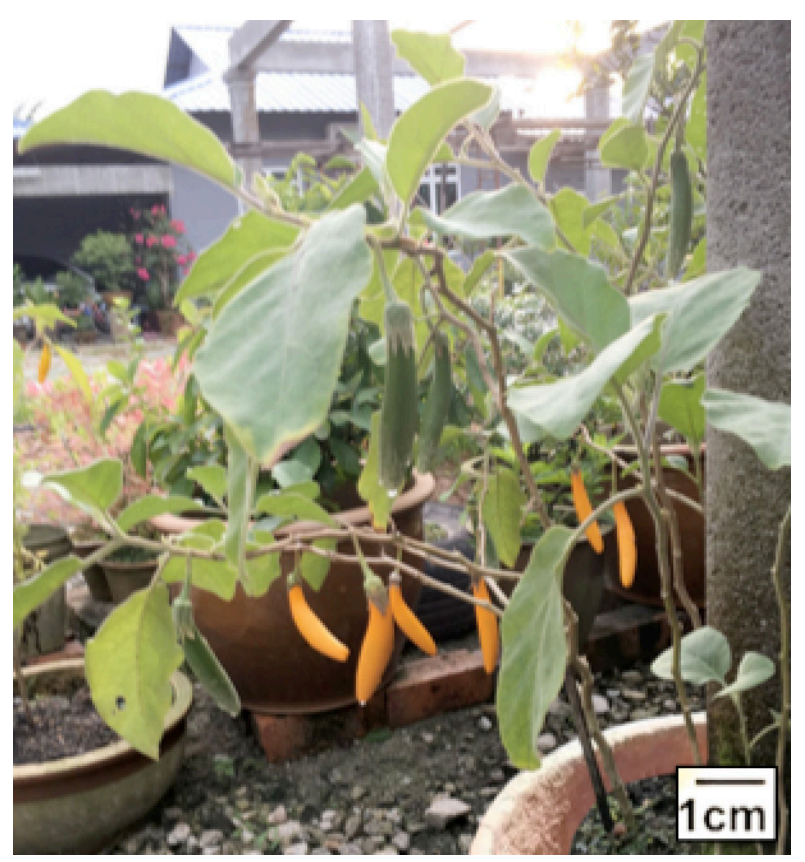

Figure 1 Finger eggplant (Solanum sp.) fruits mature as the green colour gradually turned yellow (bar $=1$ $\mathrm{cm})$. 
http://wjst.wu.ac.th

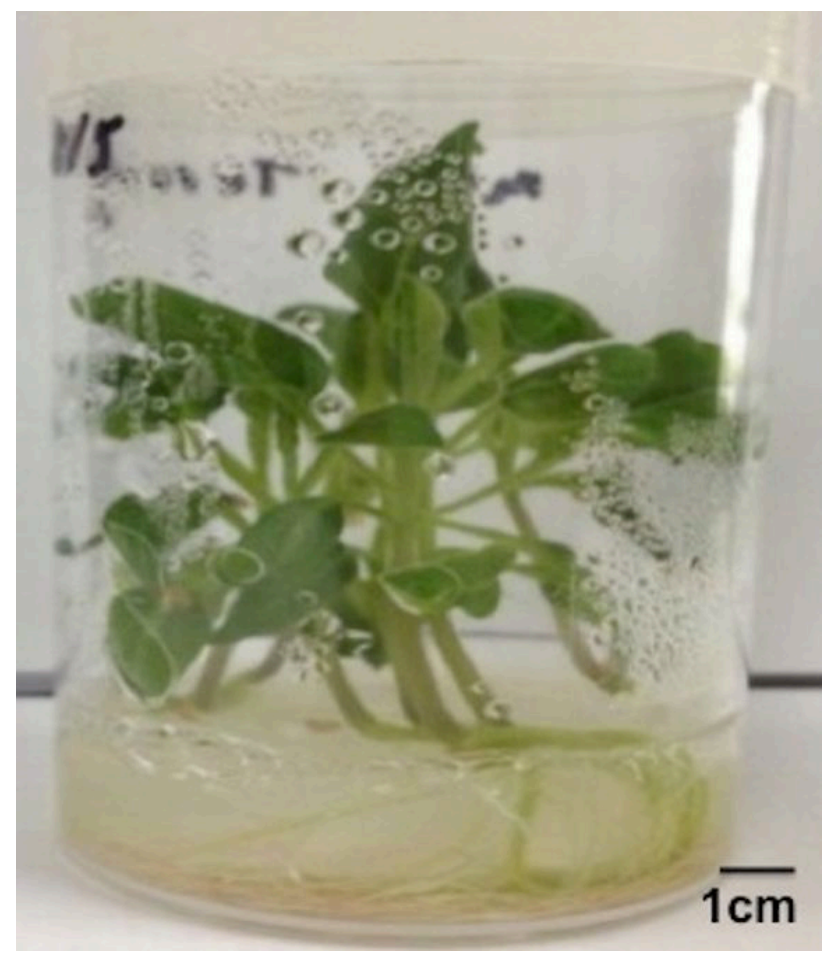

Figure 2 Sterile plantlets of finger eggplant (Solanum sp.) after 4 weeks cultured on MS basal medium consists of $4.4 \mathrm{~g} / \mathrm{L} \mathrm{MS}$ powder, $30 \mathrm{~g} / \mathrm{L}$ sucrose and $8 \mathrm{~g} / \mathrm{L}$ solidified Oxoid technical agar $(\mathrm{bar}=1 \mathrm{~cm})$.

\section{Effect of various concentrations of NAA and BAP on callus induction}

The ratio of auxin and cytokinin (NAA and BAP) is essential for callus induction of finger eggplant (Solanum sp.). Twenty explants of stems and leaf segments of each treatment were inoculated to observe their callusing response. The explants become swollen and a callus was formed along the cut portion after 2 weeks of culture. Leaf explants are comparatively more responsive for callus induction than stem explants after 4 weeks of culture (Tables 2 and 3). There was $100 \%$ callus formation on leaf and stem explants cultured in various concentrations of NAA and BAP. Callus formation on hormone-free MS medium is absent in both explants. Stem explants formed $0.14 \pm 0.05 \mathrm{~g}$ callus fresh weight with friable callus, creamy white, and light green on MS medium containing $1.0 \mathrm{mg} / \mathrm{L}$ NAA and $1.0 \mathrm{mg} / \mathrm{L} \mathrm{BAP}$ (Table 2 and Figure 3a). Meanwhile, leaf explants formed $0.48 \pm 0.10 \mathrm{~g}$ callus fresh weight with friable callus, creamy yellow, and light green when cultured on MS medium supplemented with $0.5 \mathrm{mg} / \mathrm{L}$ NAA and $2.0 \mathrm{mg} / \mathrm{L}$ BAP (Table 3 and Figure $3 \mathbf{b}$ ). The value was significantly higher $(\mathrm{p}<0.05)$ compared with other treatments. Results revealed that the leaf explants gave better callus induction than stem explants (Figure 4). The leaf explants swelled up and callus started growing at the cut surfaces on all the combinations of NAA and BAP 5 to 7 days after inoculation, while in stem explant callus started growing slower after 7 to 10 days. These indicate that callus initiation from leaf required minimum days.

The plant cell has the totipotency to contribute to callus induction. Hence, friable callus frequently grows faster than compact callus [19]. The position of the explant influences the growth in culture, as noted in several species [20]. In this experiment on finger eggplant (Solanum sp.), the distal section of leave was further cultured horizontally where the adaxial surface touches the medium. This results in agreement with [21] where leaf explants were taken from the basal part and cultured horizontally on a medium produced $100 \%$ of callus. The explant was placed horizontally on the medium showed a better ability to callus induction than those placed vertically. Explants taken from the basal part 
http://wjst.wu.ac.th

of the leaf gave the best results. A plant hormone is a key factor responsible for callus initiation [22]. The effect of NAA and BAP on callus induction from several species belonging to the Solanaceae family has been reported [23-25]. The NAA and BAP have been reported as the best hormone for callus induction [26]. The optimal concentration of these hormones may depend on many factors such as genotype of the mother plant, explant origin, and explant source [27]. It is probably due to the differences between explants and concentrations of hormones (NAA and BAP) in culture medium could be considered as differences of endogenous hormonal levels in the explant source or different tissue to these plant hormones [26]. The results showed that the highest callus induction (100\%) was observed on MS medium containing the different concentrations of NAA and BAP. The NAA and BAP have been reported as the best hormones for callus induction. Cytokinin and auxin are the commonly known plant growth regulators being widely used in callus induction as different combination ratios of these 2 would bring a significant difference in callus induction. In this study, a combination of NAA and BAP are more effective for callus induction compared to NAA and BAP alone. There is no callus initiation of cultures on MS medium without hormones. The result looks similar to the brinjal, eggplant of S. melongena L. $[17,18]$. They have confirmed that NAA and BAP treatment were effective to the initiation of callus formation from stems and leaf explants and suggested its combination of NAA and BAP play an important role in callus induction. There was a positive interaction result of NAA and BAP relatively in the production of fast grown calli in Solanum nigrum L. [27,28]. The results indicated that exogenous hormones are essential to the callus formation of finger eggplant (Solanum sp.). Generally, the callus induction through an auxin-cytokinin combination has been reported for several systems of the Solanaceae family.

Table 2 Effects of concentrations of NAA and BAP containing solidified MS medium on callus formation from stem explants of finger eggplant (Solanum sp.) after 4 weeks of culture.

\begin{tabular}{|c|c|c|c|c|}
\hline \multicolumn{2}{|c|}{$\begin{array}{l}\text { Concentration of } \\
\text { hormones }(\mathrm{mg} / \mathrm{L})\end{array}$} & \multirow{2}{*}{$\begin{array}{c}\text { Percentage of } \\
\text { callus formation } \\
(\%)\end{array}$} & \multirow{2}{*}{$\begin{array}{l}\text { Callus fresh } \\
\text { weight (g ) }\end{array}$} & \multirow[t]{2}{*}{ Morphology of callus } \\
\hline NAA & BAP & & & \\
\hline 0.0 & 0.0 & $00.00 \pm 0.0$ & $0.00 \pm 0.00$ & - \\
\hline 0.5 & 0.0 & $100.00 \pm 0.0$ & $0.09 \pm 0.02^{\mathrm{ab}}$ & Friable, Creamy white and light green \\
\hline 1.0 & 0.0 & $100.00 \pm 0.0$ & $0.06 \pm 0.01^{\mathrm{ab}}$ & Friable, Creamy white and light green \\
\hline 0.0 & 1.0 & $100.00 \pm 0.0$ & $0.11 \pm 0.040^{\mathrm{ab}}$ & Friable, Creamy white and light green \\
\hline 0.0 & 2.0 & $100.00 \pm 0.0$ & $0.10 \pm 0.03^{\mathrm{ab}}$ & Friable, Creamy white and light green \\
\hline 0.0 & 3.0 & $100.00 \pm 0.0$ & $0.05 \pm 0.02^{\mathrm{ab}}$ & Friable, Creamy white and light green \\
\hline 0.5 & 1.0 & $100.00 \pm 0.0$ & $0.08 \pm 0.02^{\mathrm{ab}}$ & Friable, Creamy white and light green \\
\hline 0.5 & 2.0 & $100.00 \pm 0.0$ & $0.12 \pm 0.05^{\mathrm{ab}}$ & Friable, Creamy white and light green \\
\hline 0.5 & 3.0 & $100.00 \pm 0.0$ & $0.11 \pm 0.04^{\mathrm{ab}}$ & Friable, Creamy white and light green \\
\hline 1.0 & 1.0 & $100.00 \pm 0.0$ & $0.14 \pm 0.05^{\mathrm{ab}}$ & Friable, Creamy white and light green \\
\hline 1.0 & 2.0 & $100.00 \pm 0.0$ & $0.07 \pm 0.01^{\mathrm{ab}}$ & Friable, Creamy white and light green \\
\hline 1.0 & 3.0 & $100.00 \pm 0.0$ & $0.06 \pm 0.02^{\mathrm{ab}}$ & Friable, Creamy white and light green \\
\hline
\end{tabular}

$\mathrm{SE}^{\mathrm{a}}=$ Standard Error. Letters a, b, c and d show statistically significant differences between the variables. The value for the same alphabet is not significantly different (Tukey's multiple range test, $p<0.05$ ). 
http://wjst.wu.ac.th

Table 3 Effects of concentrations of NAA and BAP containing solidified MS medium on callus formation from leaf explants of finger eggplant (Solanum sp.) after 4 weeks of culture.

\begin{tabular}{|c|c|c|c|c|}
\hline \multicolumn{2}{|c|}{$\begin{array}{r}\text { Concentration } \\
\text { of hormones } \\
(\mathrm{mg} / \mathrm{L}) \\
\end{array}$} & \multirow{2}{*}{$\begin{array}{c}\text { Percentage of } \\
\text { callus formation } \\
(\%)\end{array}$} & \multirow[t]{2}{*}{$\begin{array}{l}\text { Callus fresh weight } \\
\qquad(\mathrm{g} \pm \mathrm{SE})\end{array}$} & \multirow[t]{2}{*}{ Morphology of callus } \\
\hline NAA & BAP & & & \\
\hline 0.0 & 0.0 & $00.00 \pm 0.0$ & $00.00 \pm 0.00$ & - \\
\hline 0.5 & 0.0 & $100.00 \pm 0.0$ & $0.12 \pm 0.04^{\mathrm{abc}}$ & Friable, Creamy yellow and light green \\
\hline 1.0 & 0.0 & $100.00 \pm 0.0$ & $0.06 \pm 0.01^{\mathrm{a}}$ & Friable, Creamy yellow and light green \\
\hline 0.0 & 1.0 & $100.00 \pm 0.0$ & $0.09 \pm 0.07^{\mathrm{ab}}$ & Compact, Light yellow and green \\
\hline 0.0 & 2.0 & $100.00 \pm 0.0$ & $0.17 \pm 0.05^{\mathrm{abc}}$ & Compact, Light yellow and green \\
\hline 0.0 & 3.0 & $100.00 \pm 0.0$ & $0.17 \pm 0.04^{\mathrm{abc}}$ & Compact, Light yellow and green \\
\hline 0.5 & 1.0 & $100.00 \pm 0.0$ & $0.14 \pm 0.02^{\mathrm{abc}}$ & Friable, Creamy yellow and light green \\
\hline 0.5 & 2.0 & $100.00 \pm 0.0$ & $0.48 \pm 0.10^{d}$ & Friable, Creamy yellow and light green \\
\hline 0.5 & 3.0 & $100.00 \pm 0.0$ & $0.30 \pm 0.09^{\mathrm{bcd}}$ & Friable, Creamy yellow and light green \\
\hline 1.0 & 1.0 & $100.00 \pm 0.0$ & $0.28 \pm 0.07^{\mathrm{bcd}}$ & Friable, Creamy yellow and light green \\
\hline 1.0 & 2.0 & $100.00 \pm 0.0$ & $0.15 \pm 0.04^{\mathrm{abc}}$ & Friable, Creamy yellow and light green \\
\hline 1.0 & 3.0 & $100.00 \pm 0.0$ & $0.32 \pm 0.10^{\mathrm{cd}}$ & Compact, Creamy yellow and light green \\
\hline
\end{tabular}

$\mathrm{SE}^{\mathrm{a}}=$ Standard Error. Letters $\mathrm{a}, \mathrm{b}, \mathrm{c}$ and $\mathrm{d}$ indicate statistically significant differences between the variables. The value for the same alphabet is not significantly different (Tukey's multiple range test, $p<$ $0.05)$
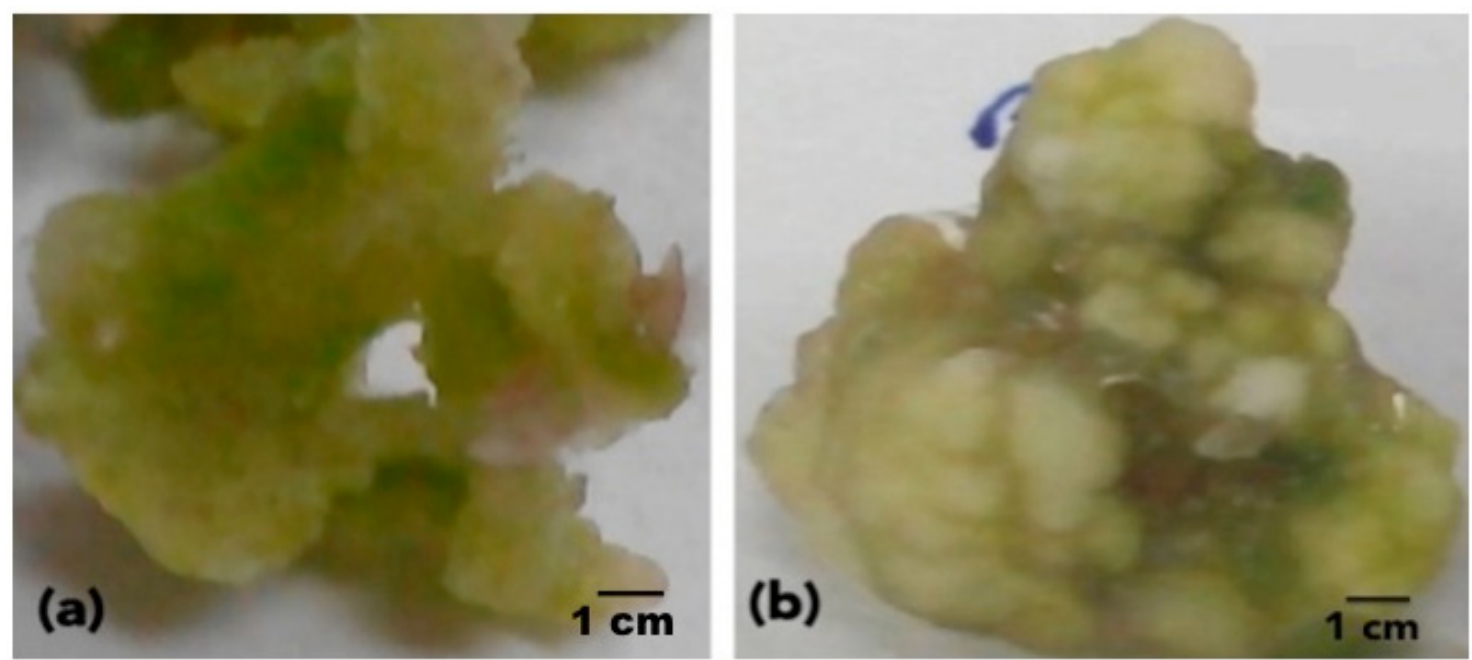

Figure 3 Callus induction of finger eggplant (Solanum sp.) after 4 weeks of culture. (a) stem explant formed friable callus on MS medium supplemented with $1.0 \mathrm{mg} / \mathrm{L} \mathrm{NAA}+1.0 \mathrm{mg} / \mathrm{L} \mathrm{BAP}$, (b) leaf explant formed friable callus on MS medium supplemented with $0.5 \mathrm{mg} / \mathrm{L} \mathrm{NAA}+2.0 \mathrm{mg} / \mathrm{L}$ BAP. (a) and (b) bar $=1 \mathrm{~cm}$. 
http://wjst.wu.ac.th

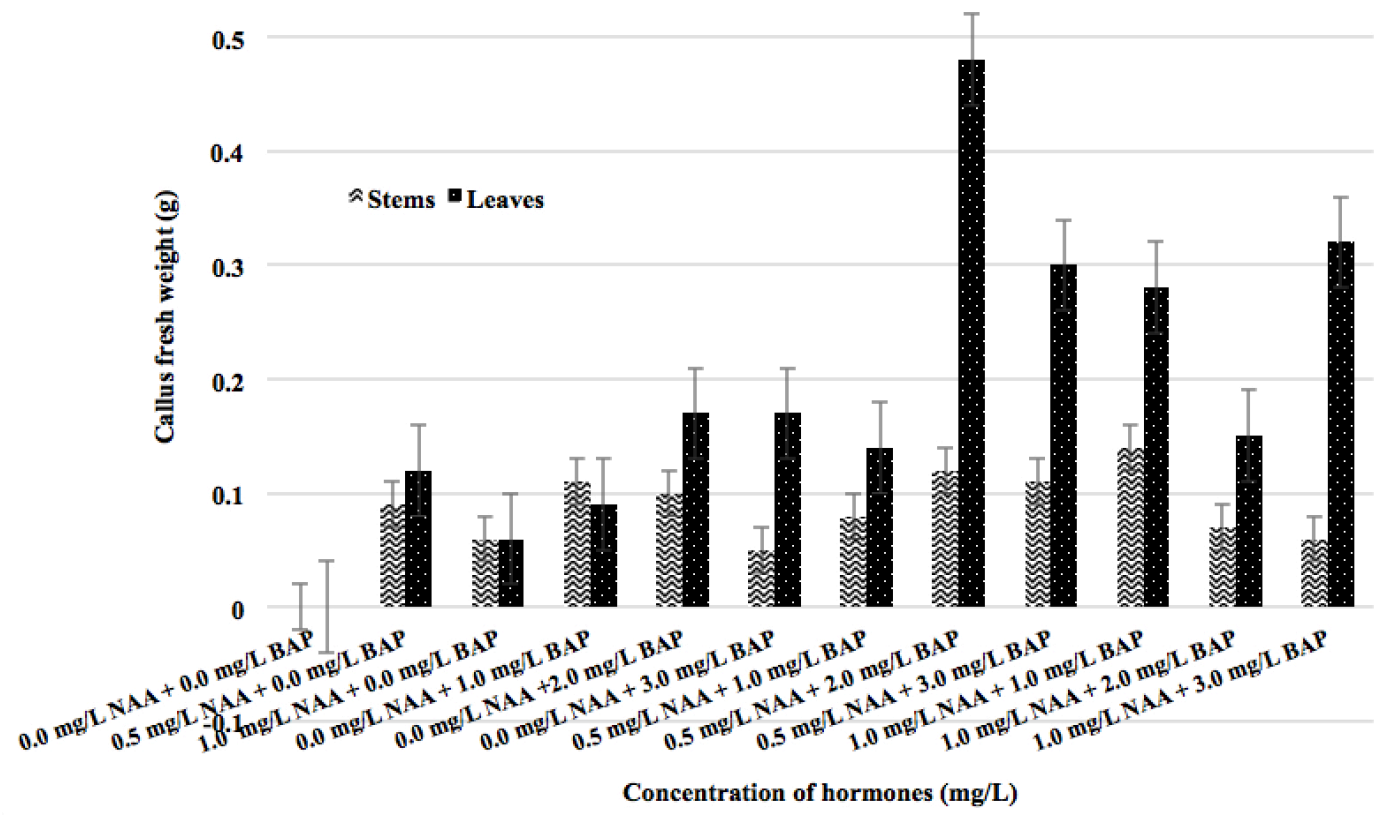

Figure 4 Callus fresh weight (g) of stems and leaf explants of finger eggplant (Solanum sp.)

\section{Extraction and phytochemical screening}

Preliminary phytochemical screening was carried out on the callus and dried leaves of Solanum sp. The dried powdered callus $(50 \mathrm{~g})$ and leaves $(100 \mathrm{~g})$ were soaked in different solvents with increasing polarity i.e. hexane, dichloromethane, and methanol. The number of materials obtained from the extract is shown in Table 4. With regards to the yield from the dried leaf samples (100 g) and callus $(50 \mathrm{~g})$ extracts, the crude extracts of samples showed no significantly dry weight with different solvents. In these experiments, $100 \mathrm{~g}$ of dried leaf samples were extracted to obtain a crude extract, while calluses were collected from leaf explants that were cultured on the best culture medium, $9.5 \mathrm{mg} / \mathrm{L} \mathrm{NAA}$ and $20.0 \mathrm{mg} / \mathrm{L}$ BAP. However, more explants are required to collect $50 \mathrm{~g}$ of callus tissue.

The extracts of dried leaves and callus in different solvents were subjected to phytochemical screening quantitatively to determine the presence of phytochemical constituents such as alkaloids, flavonoids, tannins, terpenoids and saponins, steroids and tannins. Thus, these components were extracted based on the polarity of the solvents.

The results of the phytochemical screenings in finger eggplant (Solanum sp.) are based on quantitative observations. Methanol is the best solvent for the extraction of alkaloids, flavonoids, terpenoids, and saponins (Table 5). It is considered as a polar solvent commonly used to extract a wide range of compound polarities, ranging from non-polar to water-soluble. As summarized in Table 5, each extract treated with different treatment will produce different results (positive results). No previous report of phytochemical screening of the finger eggplant (Solanum sp.) was found. However, the same result has been reported for optimizing callus growth and alkaloids production in the combination of NAA and BAP on other plants of Solanum genus, such as $S$. nigrum L. [27], S. jasminides and S. verbascifolium [30] and $S$. xanthocarpum [31]. The presence of these phenolic compounds of leaf extract has previously been found in other related species, such as Solanum torvum Swartz, S. trilobatum and S. xanthocarpum Schrad and Wendl [29]. The treatments of NAA and BAP reported leading the production of alkaloids (solasodine) on S. laciniatum [32]. Based on the reported above, alkaloids, flavonoid, terpenoids, and saponin were found on the leaves in most of the Solanaceae family.

Secondary metabolites often play an important role in plant defense against microorganism. 
http://wjst.wu.ac.th

Humans use secondary metabolites as medicines, flavorings, pigments, and recreational drugs. Some common antimicrobials in plants are phenols, phenolic acids, quinones, flavones, flavonoids, tannins, coumarins, terpenoids, alkaloids, and sugars. The preliminary phytochemical screening of extracts of Solanum nigrum showed the presence of bioactive components like flavonoids, terpenoids, saponins, sterols, phenols, and tannin. Many Solanum species are known to produce steroidal saponins such as digitogenin, and steroidal alkaloids such as tomatidine [33]. Evidence shows that the extract was also evaluated for antimicrobial activity against medically important bacteria like Escherichia coli, Staphylococcus aureus, and Bacillus subtillis [34]. Hence, phytochemical screening serves as the initial step in predicting the types of potentially active compounds for further study in the future. These results of this study might provide scientific support to the traditional claims in using finger eggplant (Solanum sp.) for medicine or food preservative purposes.

Table 4 Percentage yield of extract (\%) from the dried materials (leaves and callus) of finger eggplant (Solanum sp.)

\begin{tabular}{lcccc}
\hline \multicolumn{1}{c}{ Solvents } & $\begin{array}{c}\text { Weight of dried } \\
\text { leaves } \mathbf{( g )}\end{array}$ & $\begin{array}{c}\text { Percentage yield } \\
\text { of extract } \mathbf{( \% )}\end{array}$ & $\begin{array}{c}\text { Weight of callus } \\
\mathbf{( g )}\end{array}$ & $\begin{array}{c}\text { Percentage yield } \\
\text { of extract } \mathbf{( \% )}\end{array}$ \\
\hline Hexane & 100.00 & 1.72 & 50.00 & 1.44 \\
Dichloromethane & 100.00 & 2.15 & 50.00 & 1.72 \\
Methanol & 100.00 & 2.90 & 50.00 & 2.38 \\
\hline
\end{tabular}

Table 5 Phytochemical constituents of extract from the dried leaves and callus of finger eggplant (Solanum sp.).

\begin{tabular}{|c|c|c|c|c|c|}
\hline \multirow{2}{*}{ Extract } & \multirow{2}{*}{ Test } & \multirow{2}{*}{ Positive indicator } & \multicolumn{3}{|c|}{ Leaves extract } \\
\hline & & & Hexane & Dichloromethane & Methanol \\
\hline \multirow{2}{*}{$\begin{array}{l}\text { Leaves } \\
\text { Callus }\end{array}$} & \multirow{2}{*}{ Alkaloids } & \multirow{2}{*}{ An orange precipitate } & - & & + \\
\hline & & & - & + & + \\
\hline \multirow{2}{*}{$\begin{array}{l}\text { Leaves } \\
\text { Callus } \\
\end{array}$} & \multirow{2}{*}{ Flavonoids } & \multirow{2}{*}{ A yellow colouration } & - & & + \\
\hline & & & - & + & + \\
\hline \multirow{2}{*}{$\begin{array}{l}\text { Leaves } \\
\text { Callus }\end{array}$} & \multirow{2}{*}{ Tannins } & \multirow{2}{*}{ A green-bluish precipitation } & - & & - \\
\hline & & & - & - & - \\
\hline \multirow{2}{*}{$\begin{array}{l}\text { Leaves } \\
\text { Callus }\end{array}$} & \multirow{2}{*}{ Terpenoids } & \multirow{2}{*}{ A brown-reddish color of the interface } & + & & + \\
\hline & & & + & + & + \\
\hline Leaves & \multirow{2}{*}{ Saponins } & \multirow{2}{*}{ A white precipitation } & - & & + \\
\hline Callus & & & - & - & + \\
\hline
\end{tabular}

Legends: $(+)=$ presence of phytochemical constituent; $(-)=$ absence of phytochemical constituent.

\section{Conclusions}

A protocol to induce callus formation had been developed in the present study. The callus formation of finger eggplant (Solanum sp.) was induced from stem and leaf explants and subsequently exhibited secondary metabolites production. Plant tissue culture techniques provide a method for callus formation in rapid callus protocol and large scale for production the secondary metabolites compared to the extraction plant part from field grown. Implementation of plant tissue culture techniques that can produce large amounts of callus is necessary for secondary metabolites production that has medicinal properties. The findings are successful for further scrutiny of plant secondary metabolites in finger eggplant to be carried out. 
http://wjst.wu.ac.th

\section{Acknowledgements}

The authors would like to express gratitude to the Research Management Innovation Centre (RMIC) Universiti Pendidikan Sultan Idris for the financial support provided through Geran Penyelidikan Universiti (GPU) under short-term research grant 2016-0052-101-01.

\section{References}

[1] O Suhana, O Mohamad, MA Rahman and MAZ Akhbar. Genetic of yield and its components in eggplant (Solanum melongena L.). J. Trop. Agric. Food Sci. 2016; 44, 137-45.

[2] HC Ong. Sayuran: Khasiat makanan dan ubatan. Utusan publication \& distributor, Kuala Lumpur, 2003, p. 165.

[3] SG Sundari, S Rekha and A Parvathi. Phytochemical evaluation of three species Solanum L. Int. J. Res. Ayurveda Pharm. 2015; 4, 420-5.

[4] TM Sridhar and CV Naidu. An Efficient callus induction and plant regeneration of Solanum nigrum (L.) - an important antiulcer medicinal plant. J. Phytol. 2011; 3, 23-8.

[5] R Sarin. Useful metabolites from plant tissue cultures. Biotechnology 2005; 4, 79-93.

[6] MD Mahadev, CS Panathula and CV Naidu. Efficient protocol for in vitro callus induction and indirect plant regeneration of Solanum viarum (Dunal): An important anticancer medicinal plant. Int. J. Med. Aromat. Plants 2014; 4, 117-23.

[7] LJ Zou, JT Yang and QG Wu. A protocol for rapid and high frequency in vitro propagation of Solanum nigrum L. Sains Malays. 2017; 46, 1183-9.

[8] MA Alim, BK Biswas, M Hasanuzzaman, P Baka and UK Roy. Callus induction of brinjal by genotype and growth regulators J. Expt. Biosci. 2014; 5, 35-42.

[9] EA Ewais, SA Desouky and EH Eshazly. Studies on callus induction, phytochemical constituents and antimicrobial activity of Solanum nigrum L. (Solanaceae). Nat. Sci. 2015; 13, 1338.

[10] T Murashige and F Skoog. A revised medium for rapid growth and bioassays with tobacco tissues cultures. Physiol. Plant. 1962; 15, 473-97.

[11] BP Ray, L Hassan and SK Sarker. Plant regeneration from seedling derived explants through callus of Eggplant (Solanum melongena L.) The Agriculturists 2010; 8, 98-107.

[12] A Sofowara. Medicinal plants and traditional medicine in Africa Vol 2, Spectrum Books, Ibadan, Nigeria, 1993, p.191-288.

[13] JB Harborne. Phytochemical Methods. Chapman Hall, London, 1973, p. 49-188.

[14] JB Harborne. Phytochemical Methods: A guide to modern technique of plant analysis. Chapman Hall, London, 1984, p. 1-276.

[15] N Srivastava, B Kamal, V Sharma, YK Negi, AK Dobriyal, S Gupta and VS Jadon. Standardization of sterilization protocol for micropropagation of Aconitum heterophyllum: An endangered medicinal herb. Academic Arena. 2010; 2, 62-6.

[16] PC Debergh and RH Zimmerman. Micropropagation: Technology and Application. Kluwer Academic Publisher, The Netherlands, 1993, p. 31-44.

[17] AAG Benishelkh, Y Tijani, NK Askira, MS Waziri, AU Awana. Prevalence and management of laboratory microbial contaminants in plant tissue culture. Int. J. Res. 2015; 2, 625-30.

[18] CR Singh. Review on problems and its remedy in plant tissue culture. Asian J. Biol. Sci. 2018; 11, 165-72.

[19] MD Jamil, M Parvaiz, M Tufail, J Arshad, S Hussain and S Imtiaz. Callogenesis, regeneration of shoot and root of brinjal (Solanum melongena L.) World App. Sc. J. 2013; 26, 1039-45.

[20] BP Ray, L Hassan and KM Nasiruddin. In vitro regeneration of brinjal (Solanum melogena L.). Bangladesh J. Agril. Res. 2011; 36, 397-406.

[21] TM Sridhar and CV Naidu. An efficient callus induction and plant regeneration of Solanum nigrum (L.) - an important antiulcer medicinal plant. J. Phytol. 2011; 3, 23-8.

[22] H Cheng, LJ Yu, QY Hu, SC Chen and YP Sun. Establishment of callus and cell suspension 
http://wjst.wu.ac.th

cultures of Corydalis saxicola bunting, a rare medicinal plant. Z. Naturforsch. 2006; 61, 251-6.

[23] M Solouki, H Hoshyar, M Ramroudi and A Tavassoli. Comparison and evaluation of steroid alkaloid solasodine on in vivo and in vitro cultures of Solanum surayyense Burm. L. African J. Microbiol. Res. 2011; 5, 3810-4.

[24] P Govindarajan and C Chinnachamy. Phytochemical and therapeutic evaluation of leaf and in vitro derived callus and shoot of Solanum trilobatum. Pak. J. Pharm. Sci. 2014; 27, 2101-7.

[25] EA Ewais, SA Desouky and EH Eshazly. Studies on callus induction, phytochemical constituents and antimicrobial activity of Solanum nigrum L. (Solanaceae). Nat. Sci. 2015; 13, 133-8.

[26] A Biswas, M Roy, MAB Miah and SK Bhadra. Plant tissue culture. Biotechnology 2007; 17, 5964.

[27] S Mathur and GS Shekhawat. Establishment and characterization of Stevia rebaudiana (Bertoni) cell suspension culture: An in vitro approach for production of stevioside. Acta. Physiol. Plant. 2013; 35, 931-9.

[28] SR Blashing. Regeneration and heavy formation in some medicinally important members of family Solanaceae. Adv. Plant Sci. 2000; 11, 253-7.

[29] MA Firoz, ME Uddin, R Amin, MA Razzak, MA Manik and MM Khatun. Studies on the effect of various sterilization procedures for in vitro seed germination and successful micropropagation of Cucumis sativus. Int. J. Pure App. Biosci. 2016; 4, 75-81.

[30] SC Jain, SL Sahoo and R Vijayverga. Influence of light on light on growth and production of steroids and glycolalkaloids in Solanum species in vivo and in vitro. Indian J. Pharm. Sci. 1995; 57, 100-1.

[31] R Zafar and P Humayun. Quantification of solasodine in callus and suspension cultures of Solanum xanthocarpum Achrad. \& Wendl. By RP-HPLC. Int. J. Pharm. Phytochem. Res. 2015; 7, 206-14.

[32] SF Chandler. Solasodine yield in callus cultures of Solanum laciniatum selected for growth on hormone free medium. Ann. Bot. 1984; 54, 293.

[33] N Yoganth, R Bhakyaraj, A Chanthuru, S Parvathi and S Palanivel. Comparative analysis of solasodine from in vitro and in vivo cultures of Solanum nigrum. Linn. J. Sci. Eng. Tech. 2009; 5, 99-103.

[34] R Zafar and P Humayun. Quantification of solasodine in callus and suspension cultures of Solanum xanthocarpum Achrad. \& Wendl. By RP-HPLC. Int. J. Pharm. Phytochem. Res. 2015; 7, 206-14.

[35] MA Firoz, ME Uddin, R Amin, MA Razzak, MA Manik and MM Khatun. Studies on the effect of various sterilization procedures for in vitro seed germination and successful micropropagation of Cucumis sativus. Int. J. Pure. App. Biosci. 2016; 4, 75-81.

[36] SF Chandler. Solasodine yield in callus cultures of Solanum laciniatum selected for growth on hormone free medium. Ann. Bot. 1984; 54, 293.

[37] R Duperon, M Thiersault and P Duperon. High level of glycosylated sterols in species of Solanum and sterol changes during the development of tomato. Phytochemistry 1984; 23, 743-6.

[38] MU Vaishvedhidha, P Ezilrani, G Christopher and J Godwin. Phytochemical and antimicrobial properties of Cardiospermumhali cacabum and Solanum nigrum. Res. J. Pharm. Tech. 2015; 8, 1417-22. 